\title{
GMR
}

\section{Characterization and application of newly developed polymorphic microsatellite markers in the Ezo red fox (Vulpes vulpes schrencki)}

\author{
T. Tada ${ }^{1}$, Y. Seki ${ }^{2}$, Y. Kameyama ${ }^{1}$, Y. Kikkawa ${ }^{2}$ and K. Wada ${ }^{1,2}$ \\ ${ }^{1}$ Graduate School of Bioindustry, Tokyo University of Agriculture, Abashiri, \\ Hokkaido, Japan \\ ${ }^{2}$ Mammalian Genetics Project, Department of Genome Medicine, \\ Tokyo Metropolitan Institute of Medical Science, Tokyo, Japan \\ Corresponding author: K. Wada \\ E-mail: k3wada@bioindustry.nodai.ac.jp
}

Genet. Mol. Res. 15 (4): gmr15049104

Received August 30, 2016

Accepted October 24, 2016

Published December 19, 2016

DOI http://dx.doi.org/10.4238/gmr15049104

Copyright $(C 2016$ The Authors. This is an open-access article distributed under the terms of the Creative Commons Attribution ShareAlike (CC BY-SA) 4.0 License.

\begin{abstract}
The Ezo red fox (Vulpes vulpes schrencki), a subspecies endemic to Hokkaido island, Japan, is a known host species for the tapeworm Echinococcus multilocularis. To develop tools for molecular ecological studies, we isolated 28 microsatellite regions from the genome of Ezo red fox, and developed 18 polymorphic microsatellite markers. These markers were characterized using 7 individuals and 22 fecal samples of the Ezo red fox. The number of alleles for these markers ranged from 1 to 7 , and the observed heterozygosity, estimated on the basis of the genotypes of 7 individuals, ranged from 0.29 to 1.00 . All markers, except DvNok5, were in Hardy-Weinberg equilibrium $(\mathrm{P}>0.05)$, and no linkage disequilibrium was detected among these loci, except between DvNok14 and DvNok28 $(\mathrm{P}=0.01)$. Moreover, six microsatellite loci were successfully genotyped using feces-derived
\end{abstract}


DNA from the Ezo red fox. The markers developed in our study might serve as a useful tool for molecular ecological studies of the Ezo red fox.

Key words: Vulpes vulpes schrencki; Polymorphic microsatellite marker; Feces-derived DNA

\section{INTRODUCTION}

The red fox (Vulpes vulpes) is one of the most widely distributed terrestrial carnivores in the world, and occurs throughout most of North America, Europe, Asia, and North Africa (Larivière and Pasitschniak-Arts, 1996). The Japanese red foxes can be subdivided into two subspecies - the Japanese red fox ( $V$. v. japonica) and the Ezo red fox ( $V . v$. schrencki) - based on their habitat differences. The Ezo red fox is an endemic subspecies on the island of Hokkaido, located at the north end of Japan, and is a known final host of the tapeworm Echinococcus multilocularis, which causes the serious zoonosis alveolar echinococcosis (Oku and Kamiya, 2003). To manage the population size of the Ezo red fox and prevent the spread of tapeworm infection, it is important to characterize the ecological features of this subspecies. However, detailed ecological features of the Ezo red fox, such as its social structure and home range at the population level, have not yet been clarified.

Polymorphic genetic markers are useful tools for the ecological studies of wild animals. Specifically, a microsatellite marker is composed of one to six nucleotide repeats, and is advantageous for molecular ecology research owing to its high polymorphism and easy allele detection compared with other DNA markers (Mowat and Strobeck, 2000; Creel et al., 2003; Eggert et al., 2003; Prugh et al., 2005; Piggott et al., 2006). Several microsatellite markers have been developed for foxes belonging to the genus Vulpes (Wandeler and Funk, 2006; Yan et al., 2015; Yu et al., 2015). These markers enable the analyses of genetic diversity and population structure of the local species of Vulpes. However, polymerase chain reaction (PCR) failure is occasionally observed when markers developed for different species are used in the analyses of local populations (Oishi et al., 2011), indicating the existence of sequence differences in the flanking DNA of repeat regions among local populations of Vulpes. Therefore, we suggest that polymorphic microsatellite markers specific to the Ezo red fox genome are necessary for the accurate identification of animals and characterization of their population structure and ecological features.

In this study, we isolated 28 microsatellite regions from the genome of Ezo red fox, and developed 18 novel polymorphic microsatellite markers. Moreover, we confirmed that several of these markers can even be amplified from the feces-derived DNA.

\section{MATERIAL AND METHODS}

The livers of the Ezo red foxes were collected from Abashiri, Shari, and Utoro, which are located at the east end of Hokkaido, Japan, from June to October 2012. All livers were collected from road-killed animals. Feces were collected from Abashiri from August 2008 to October 2009 and from February to October 2010. To inactivate Echinococcus eggs, all samples were stored at $-70^{\circ} \mathrm{C}$ for more than $24 \mathrm{~h}$. Genomic DNA from liver samples was extracted using the Gentra Puregene Tissue Kit (Qiagen, Valencia, CA, USA). Feces-derived DNA was extracted from $200 \mathrm{mg}$ feces using the QIAamp DNA Stool Mini Kit (Qiagen). All

Genetics and Molecular Research 15 (4): gmr15049104 
experimental procedures were approved by the Animal Care and Use Committee of the Tokyo University of Agriculture (Approval No.: 270047).

First, we estimated the quality of extracted DNA by PCR-amplifying the partial Cytochrome $b(C y t b)$ gene using a pair of universal primers, L14841 and H15149 (Kocher et al., 1989). We extracted DNA from 214 fecal samples, and confirmed the PCR amplification of the Cytb gene in 192 feces-derived DNA samples. Microsatellite regions were isolated using a standard procedure (Glenn and Schable, 2005; Seki et al., 2012). Approximately $5 \mu \mathrm{g}$ genomic DNA was digested with XmnI and RsaI restriction enzymes (New England Biolabs Japan Inc., Sumida-ku, Tokyo, Japan). Subsequently, the excised DNA fragments were ligated to SuperSNX24 Forward (5'-GTT TAA GGC CTA GCT AGC AGA ATC-3') and SuperSNX24 + 4P Reverse (5'-p-GAT TCT GCT AGC TAG GCC TTA AAC AAA A-3') linkers. The fragments with linkers were enriched for microsatellite repeats by hybridization to a 3'-biotinylated microsatellite $\left(\mathrm{GT}_{12}\right)$ probe, followed by capture on Dynabeads (Thermo Fisher Scientific, Rockford, IL, USA). The captured fragments were then amplified by PCR using the SuperSNX24 Forward primer. The purified PCR-products were ligated to the pT7Blue T-vector (Novagen, Madison, WI, USA), and transformed into ECOS-competent Escherichia coli JM109 (Nippon Gene, Chiyoda-ku, Tokyo, Japan). The cloned inserts were amplified and sequenced using the universal M13 primers, P7 and P8 (Seki et al., 2012).

In order to characterize the microsatellite markers, a fragment analysis was carried out using organ-derived DNA from 7 individuals and 192 feces-derived DNA samples. To amplify microsatellite regions of the fox genome, PCR was performed in a total volume of $10 \mu \mathrm{L}$ with genomic DNA (less than $50 \mathrm{ng}$ ), $2.6 \mu \mathrm{M}$ fluorescent-labeled primers (Beckman Dye 2, 3, and 4; Sigma-Aldrich, St. Louis, MO, USA), $0.2 \mathrm{mM}$ dNTPs, $1.5 \mathrm{mM} \mathrm{MgCl}, 1 \mathrm{X}$ PCR Gold Buffer, $1 \mathrm{M}$ betaine, and $0.5 \mathrm{U}$ AmpliTaq Gold DNA Polymerase (Thermo Fisher Scientific). The following PCR cycling program was used: initial denaturation at $95^{\circ} \mathrm{C}$ for 10 min; 55 cycles of denaturation at $94^{\circ} \mathrm{C}$ for $30 \mathrm{~s}$, annealing at $55^{\circ} \mathrm{C}$ for $30 \mathrm{~s}$, and extension at $72^{\circ} \mathrm{C}$ for $1 \mathrm{~min}$; and final extension at $72^{\circ} \mathrm{C}$ for $5 \mathrm{~min}$. PCR-product sizes were determined using a CEQ8000 Genetic Analyzer (Sciex, Ontario, Canada), and the genotype data were analyzed using GENEPOP 4.2 (Rousset, 2008).

\section{RESULTS AND DISCUSSION}

First, we used a basic local alignment search tool (BLAST) to identify unreported DNA fragments within the cloned genomic DNA sequences, obtaining 18 novel microsatellite regions within the genome of Ezo red fox (Table 1). Based on a comparative genetic map between Canis familiaris and V. vulpes (Kukekova et al., 2007), 17 of 18 sequences could be broadly mapped onto the autosomal and sex chromosomes, except for the chromosomes 4, 5 , 10, 12, 15, and 16 of the Ezo red fox (Table 1).

Using genomic DNA extracted from the livers of 7 Ezo red fox individuals, the 18 microsatellite regions were amplified. With the exception of $D v N o k 5$, polymorphisms were identified for the remaining 17 markers. The number of alleles per locus ranged from 3 to 7, with an average of 4.41 (Table 1). $H_{\mathrm{E}}$ ranged from 0.27 to 0.85 , with an average of 0.73 , and $H_{\mathrm{O}}$ ranged from 0.29 to 1.00 , with an average of 0.72 . Except for DvNok5, all of the analyzed markers showed no deviation from Hardy-Weinberg equilibrium (HWE; P > 0.1). The deviation of DvNok5 from HWE was attributed to its low polymorphism and the small sample size used in this analysis.

Genetics and Molecular Research 15 (4): gmr15049104 
T. Tada et al.

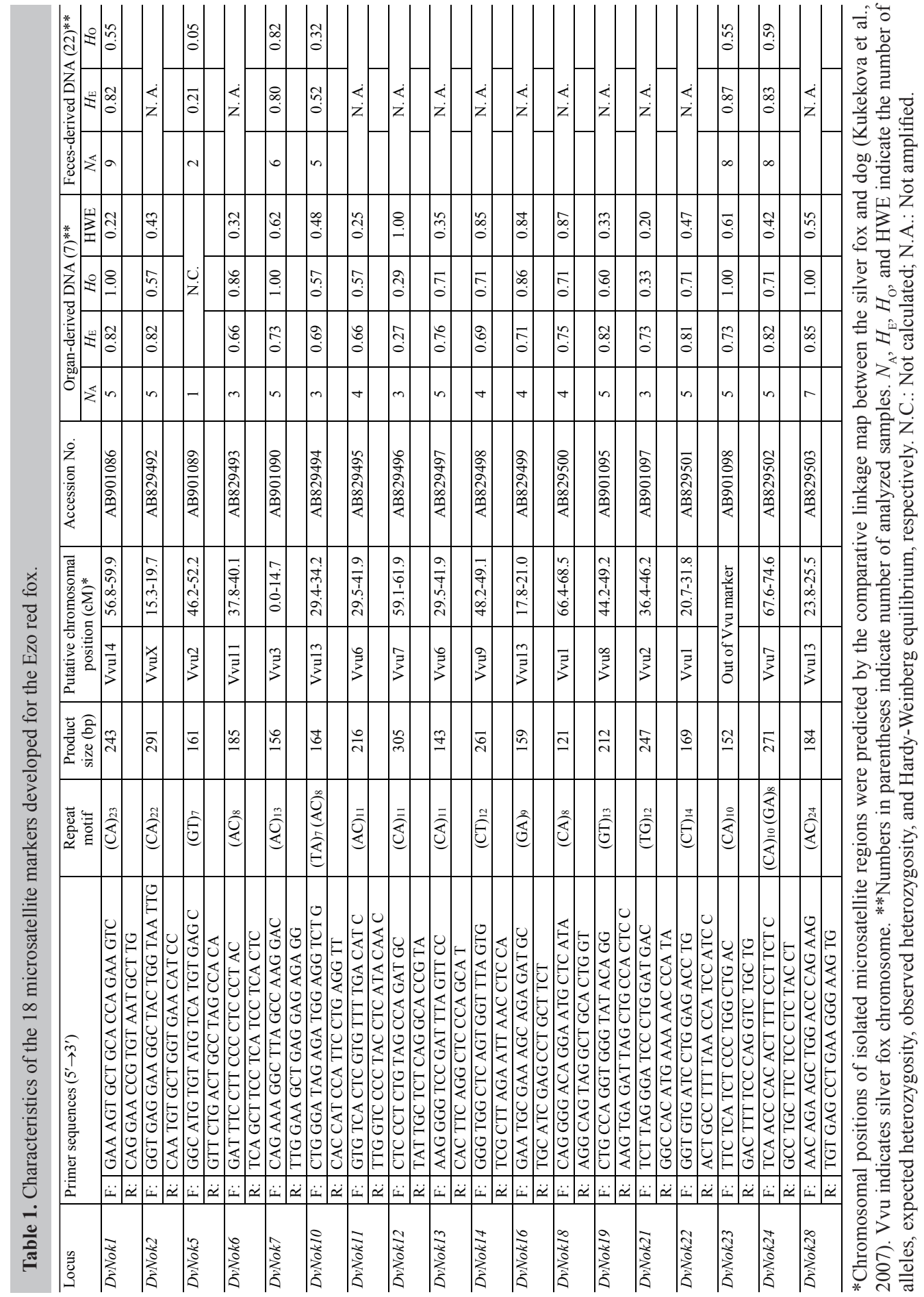

Genetics and Molecular Research 15 (4): gmr15049104 
Oishi et al. (2011) reported that the average number of alleles per locus in the populations of Ezo red fox in the southern, central, northern, eastern, and south-eastern regions of Hokkaido were 4.78, 7.11, 8.22, 6.33, and 5.22, respectively. Although we genotyped only a few individuals, a moderate number of alleles (3-7) was detected for all 17 markers. Thus, we successfully developed highly polymorphic microsatellite markers for the Ezo red fox.

To verify the utility of the microsatellite markers developed in this study for molecular ecology analyses in the Ezo red fox, we performed PCR using feces-derived DNA obtained from the fecal samples collected from natural fields. It should be noted that the non-invasive sampling methods, such as the collection of feces from natural fields, usually involves contamination. The DNA extracted from such samples often exhibits low quality and quantity, which can lead to reduced PCR success rates (Gagneux et al., 1997; Morin et al., 2001; Piggott and Taylor, 2003; Piggott et al., 2006; Mucci and Randi, 2007). We attempted to amplify 18 microsatellite markers using 192 fecal DNA samples, and we successfully genotyped 6 markers in 22 fecal DNA samples. The number of alleles per locus ranged from 2 to 9 , with an average of $6.33 . H_{0}$ ranged from 0.05 to 0.82 , with an average of 0.48 , and $H_{\mathrm{E}}$ ranged from 0.21 to 0.87 , with an average of 0.68 (Table 1). Although a relatively low genotyping success rate was observed in our study, these novel markers enabled genotype determination using fecal DNA samples. Therefore, we suggest that 6 of our 18 newly developed microsatellite markers are useful for ecological research on the Ezo red fox. To the best of our knowledge, our study is the first report on the development of microsatellite markers for the Ezo red fox, and includes a microsatellite marker-based analysis of its genome using feces-derived DNA.

Recently, next-generation sequencing (NGS) methods have enabled us to obtain sequence information for numerous DNA fragments in non-model organisms (Rico et al., 2013). For example, in the Korean red fox, NGS was used to sequence $65,562,274$ bp of highquality DNA, followed by the identification of 200 repeat sequences with high copy numbers; this in turn, led to the successful development of 25 novel microsatellite markers (Yu et al., 2015). Our study indicated a relatively low success rate of genotyping based on an analysis of feces-derived DNA from the Ezo red fox. Therefore, numerous microsatellite markers should be developed in future, and an optimal marker set should be selected for feces-derived DNA analyses. We recommend the use of NGS for identification of numerous microsatellite markers in the genome of Ezo red fox for conducting molecular ecological studies such as the elucidation of its genetic diversity and population structure.

\section{Conflicts of interest}

The authors declare no conflict of interest.

\section{ACKNOWLEDGMENTS}

We thank Harusa Matsui and Yasumasa Orii for technical assistance. Research supported by a Grant-in-Aid for Advanced Study Projects from Tokyo University of Agriculture, Japan.

Genetics and Molecular Research 15 (4): gmr15049104 


\section{REFERENCES}

Creel S, Spong G, Sands JL, Rotella J, et al. (2003). Population size estimation in Yellowstone wolves with error-prone noninvasive microsatellite genotypes. Mol. Ecol. 12:2003-2009.http://dx.doi.org/10.1046/j.1365-294X.2003.01868.x

Eggert LS, Eggert JA and Woodruff DS (2003). Estimating population sizes for elusive animals: the forest elephants of Kakum National Park, Ghana. Mol. Ecol. 12: 1389-1402.http://dx.doi.org/10.1046/j.1365-294X.2003.01822.x

Gagneux P, Boesch C and Woodruff DS (1997). Microsatellite scoring errors associated with noninvasive genotyping based on nuclear DNA amplified from shed hair. Mol. Ecol. 6: 861-868. http://dx.doi.org/10.1111/j.1365-294X.1997. tb00140.x

Glenn TC and Schable NA (2005). Isolating microsatellite DNA loci. Methods Enzymol. 395: 202-222. http://dx.doi. org/10.1016/S0076-6879(05)95013-1

Kocher TD, Thomas WK, Meyer A, Edwards SV, et al. (1989). Dynamics of mitochondrial DNA evolution in animals: amplification and sequencing with conserved primers. Proc. Natl. Acad. Sci. USA 86: 6196-6200. http://dx.doi. org/10.1073/pnas.86.16.6196

Kukekova AV, Trut LN, Oskina IN, Johnson JL, et al. (2007). A meiotic linkage map of the silver fox, aligned and compared to the canine genome. Genome Res. 17: 387-399. http://dx.doi.org/10.1101/gr.5893307

Larivière S and Pasitschniak-Arts M (1996). Vulpes vulpes. Mamm. Species 537: 1-11. http://dx.doi.org/10.2307/3504236

Morin PA, Chambers KE, Boesch C and Vigilant L (2001). Quantitative polymerase chain reaction analysis of DNA from noninvasive samples for accurate microsatellite genotyping of wild chimpanzees (Pan troglodytes verus). Mol. Ecol. 10: 1835-1844.http://dx.doi.org/10.1046/j.0962-1083.2001.01308.x

Mowat G and Strobeck C (2000). Estimating population size of grizzly bears using hair capture, DNA profiling, and markrecapture analysis. J. Wildl. Manage. 64: 183-193. http://dx.doi.org/10.2307/3802989

Mucci N and Randi E (2007). Sex identification of Eurasian otter (Lutra lutra) non-invasive DNA samples using ZFX/ ZFY sequences. Conserv. Genet. 8: 1479-1482. http://dx.doi.org/10.1007/s10592-007-9303-5

Oishi T, Uraguchi K, Takahashi K and Masuda R (2011). Population structures of the red fox (Vulpes vulpes) on the Hokkaido Island, Japan, revealed by microsatellite analysis. J. Hered. 102: 38-46. http://dx.doi.org/10.1093/jhered/esq091

Oku Y and Kamiya M (2003). Progress of Medical Parasitology in Japan: Biology of Echinococcus. (M. Otsuru, S. Kamegai and S. Hayashi, eds.). Meguro Parasitological Museum, Tokyo, 293-318.

Piggott MP and Taylor AC (2003). Remote collection of animal DNA and its applications in conservation management and understanding the population biology of rare and cryptic species. Wildl. Res. 30: 1-13. http://dx.doi.org/10.1071/WR02077

Piggott MP, Banks SC, Stone N, Banffy C, et al. (2006). Estimating population size of endangered brush-tailed rockwallaby (Petrogale penicillata) colonies using faecal DNA. Mol. Ecol. 15: 81-91. http://dx.doi.org/10.1111/j.1365294X.2005.02783.x

Prugh LR, Ritland CE, Arthur SM and Krebs CJ (2005). Monitoring coyote population dynamics by genotyping faeces. Mol. Ecol. 14: 1585-1596.http://dx.doi.org/10.1111/j.1365-294X.2005.02533.x

Rico C, Normandeau E, Dion-Côté AM, Rico MI, et al. (2013). Combining next-generation sequencing and online databases for microsatellite development in non-model organisms. Sci. Rep. 3: 3376. http://dx.doi.org/10.1038/srep03376

Rousset F (2008). genepop'007: a complete re-implementation of the genepop software for Windows and Linux. Mol. Ecol. Resour. 8: 103-106. http://dx.doi.org/10.1111/j.1471-8286.2007.01931.x

Seki Y, Yokohama M, Ishikawa D, Ikehara N, et al. (2012). Development and characterization of 260 microsatellite loci in the domestic goat, Capra hircus. Anim. Genet. 43: 365-366. http://dx.doi.org/10.1111/j.1365-2052.2011.02262.x

Wandeler P and Funk SM (2006). Short microsatellite DNA markers for the red fox (Vulpes vulpes). Mol. Ecol. Notes 6: 98-100. http://dx.doi.org/10.1111/j.1471-8286.2005.01152.x

Yan SQ, Bai CY, Qi SM, Li YM, et al. (2015). Development of novel polymorphic microsatellite markers for the silver fox (Vulpes vulpes). Genet. Mol. Res. 14: 5890-5895.http://dx.doi.org/10.4238/2015.June.1.6

Yu JN, Chung CU, Oh KH, Lee BK, et al. (2015). Development of novel microsatellite markers for conservation genetic studies of Vulpes vulpes (Canidae) by using next-generation sequencing method. Genet. Mol. Res. 14: 3980-3983. http://dx.doi.org/10.4238/2015.April.27.12

Genetics and Molecular Research 15 (4): gmr15049104 